\title{
Forthcoming Articles
}

The following is a list of Perception \& Psychophysics articles that are currently in press. They are given in approximate order of acceptance. Each entry includes the address and initials (in parentheses) of the author with whom to communicate for further prepublication information.

Two-month old infants' sensitivity to allophonic differences.

E.A. HOHNE \& P.W. JUSCZYK

(P.W.J.) Dept. of Psychology, SUNY at Buffalo, Park Hall, Buffalo, NY 14260-4110

Iontophoretically applied potassium ions as an experimental pain stimulus for investigating pain mechanisms.

S. HUMPHRIES, N.R. LONG, \& M.H. JOHNSON-

(S.H.) Dept. of Psychology, Massey Univ., Palmerston North, New Zealand

The effect of gap depth on the perception of whether a gap is crossable.

Y. JIANG \& L.S. MARK-

(L.S.M.) Dept. of Psychology, Miami Univ., Oxford, OH 45056

Contrasting task demands alter the perceived duration of brief time intervals.

T.F. SAWYER, P.J. MEYERS, \& S.J. HUSER-

(T.F.S.) Dept. of Psychology, North Central College, 30 N. Brainard St., P.O. Box 3063 ,

Naperville, IL 60566-7063

Vertical similarity in spoken word recognition: Multiple lexical activation, individual differences and

the role of sentence context.

C.M. CONNINE, D.G. BLASKO, \& J. WANG-

(C.M.C.) Dept. of Psychology, SUNY at Binghamton, Binghamton, NY 13760

Inhibition and disinhibition of return: Evidence from temporal order judgments.

B.S. GIBSON \& H. EGETH-

(B.S.G.) Dept. of Psychology, Univ. of Notre Dame, Notre Dame, IN 46556

Tests of human olfactory function: Principal components analysis suggests that most measure a common source of variance.

R.L. DOTY, R. SMITH, D.A. MCKEOWN, \& J. RAJ-

(R.L.D.) Smell and Taste Center, Univ. of Penn., 3400 Spruce St., Philadelphia, PA 19104-4283

Very short-term recognition memory for odors.

C. JEHL, J.-P. ROYET, \& A. HOLLEY-

(C.J.) Lab. de Physiologie Neuro., Univ. Claude-Bernard, 43, Bd du 11 novembre 1918, Villeurbanne

Cedex 69622, France

Local and global processes in surface lightness perception.

J. CATALIOTTI \& A. GILCHRIST-

(A.G.) Dept. of Psychology, Rutgers Univ., 101 Warren St., Newark, NJ 07102

Magnitude of luminance modulation specifies amplitude of perceived movement.

J. ALLIK \& A. PULVER-

(J.A.) Dept. of Psychology, Univ. of Tartu, 78 Tiigi St., Tartu EE-2400, Estonia

Heuristic judgment of mass ratio in two-body collisions.

D.L. GILDEN \& D.R. PROFFITT-

(D.L.G.) Dept. of Psychology, Mezes 330, Univ. of Texas, Austin, TX 78712

Size scaling and its effect on letter detection.

P. GOOLKASIAN-

(P.G.) Dept. of Psychology, Univ. of North Carolina, Charlotte, NC 28223

Light and dark adaptation of visually perceived eye level controlled by visual pitch.

L. MATIN \& W. LI-

(L.M.) Dept. of Psychology, Columbia Univ., New York, NY 10027 
A model for realism of confidence judgments: Implications for underconfidence in sensory discrimination.

W.R. FERRELL-

(W.R.F.) Systems and Industrial Engineering Dept., Univ. of Arizona, Tucson, AZ 85721

Detection of heteroquality taste mixtures.

J.C. STEVENS-

(J.C.S.) John B. Pierce Lab., 290 Congress Ave., New Haven, CT 06519

Does perceived size depend on perceived distance? An argument from extended haptic perception.

D. BARAC-CIKOJA \& M.T. TURVEY-

(D.B.) Ctr. for Auditory and Speech Sci., Gallaudet Univ., 800 Florida Ave. NE, Washington, DC 20002-3695

Inertial acceleration as a measure of linear vection: An alternative to magnitude estimation.

T.R. CARPENTER-SMITH, R.G. FUTAMURA, \& D.E. PARKER-

(T.R.C.) Ctr. for Professional Education, Arthur Andersen, 1405 N. Fifth Ave., St. Charles, IL 60174

Time, change, and motion: The effects of stimulus movement on temporal perception.

S.W. BROWN-

(S.W.B.) Dept. of Psychology, Univ. of Southern Maine, Portland, ME 04103

Visual search for singleton feature targets within and across feature dimensions.

H.J. MÜLLER, D. HELLER, \& J. ZIEGLER-

(H.J.M.) Dept. of Psychology, Birkbeck College, Malet St., London WC1E 7HX, England

Target and nontarget grouping in visual search.

J. DUNCAN-

(J.D.) MRC Applied Psychology Unit, 15 Chaucer Rd, Cambridge, CB2 2EF, England

Evidence for a central represenation of instrument timbre.

M.A. PITT-

(M.A.P.) Dept. of Psychology, Ohio State Univ., 1885 Neil Ave., Columbus, OH 43210-4048

Differences in influence between pitched-from-vertical lines and slanted-from-frontal horizontal lines on egocentric localization.

W. LI \& L. MATIN-

(W.L.) Dept. of Psychology, Columbia Univ., New York, NY 10027

Contextual effects in difference judgments.

H.N.J. SCHIFFERSTEN -

(H.N.J.S.) Dept. of Marketing \& Marketing Research, Agricultural Univ., Bomenweg 2, 6703 HD Wageningen, The Netherlands

Comparison of the effect of onset asynchrony on auditory grouping in pitch matching and vowel identification.

R.W. HUKIN \& C.J. DARWIN-

(C.J.D.) Experimental Psychology, Univ. of Sussex, Brighton BN1 9QG, England

The role of fundamental frequency in signaling linguistic stress and affect: Evidence for a dissociation.

G.W. MCROBERTS, M. STUDDERT-KENNEDY, \& D.P. SHANKWEILER-

(G.W.M.) Dept. of Psychology, Stanford Univ., Stanford, CA 94305-2180

Spectral redundancy: Intelligibility of sentences heard through narrow spectral slits.

R.M. WARREN, K.R. RIENER, J.A. BASHFORD, JR., \& B.S. BRUBAKER-

(R.M.W.) Dept. of Psychology, Univ. of Wisconsin, Garland Hall, P.O. Box 413, Milwaukee, WI 53201

Cuing mechanisms in auditory signal detection.

R. HÜBNER \& E.R. HAFTER-

(R.H.) Institut für Psychologie, Tech. Univ. Braunschweig, Spielmannstr. 19, Braunschweig D-38106, Germany

Temporal summation of $500-\mathrm{Hz}$ tones and octave-band noise bursts in infants and adults.

K.M. BERG \& A.E. BOSWELL-

(K.M.B.) Inst. for Advanced Study of the Comm. Processes, 63 Dauer Hall, Univ. of Florida, Gainesville, FL 32611

Temporal interval production and processing in working memory.

C. FORTIN \& R. BRETON-

(C.F.) Univ. Laval, Ecole de Psychologie, Lab. de Recherche en Psychol. Cognitive, Quebec G1K 7P4, Canada

The time course of recognition of novel melodies.

W.J. DOWLING, S. KWAK, \& M.W. ANDREWS-

(W.J.D.) Univ, of Texas at Dallas, Program in Cognitive Science, Richardson, TX 75083-0688 